Literary translation and soft power: African literature in Chinese translation

Kathryn Batchelor

orcid.org/0000-0002-9633-5782

Professor of Translation Studies,

Centre for Translation Studies (CenTraS)

UCL, UK

School of European Languages and Cultures (SELCS)

University College London

Gower Street

London WC1E 6BT

k.batchelor@ucl.ac.uk 


\title{
Literary translation and soft power: African literature in Chinese translation
}

\begin{abstract}
In the context of competing and conflicting discourses about the intensification of relations between China and Africa in the $21^{\text {st }}$ century, this article explores the potential for gaining insight into China-Africa relations through a study of literary translation activities. The article presents the results of a survey of African literature translated into Chinese between 2000 and 2015 and argues that the majority of the translations can be linked with commercial motivations. However, the article also identifies a number of exceptions to this pattern and investigates these on a case by case basis, taking into account the political connections of the authors and drawing on interviews with the Chinese publishing houses. The article argues that literary translation can be connected with the cultivation of good political relations at the highest levels, as well as with the promotion of Sino-African friendship and of a positive view of China. The article asks whether such translation projects can be, or should be, classified as tools of 'soft power' (Nye 2004), and reflects more generally on the usefulness of the soft power concept for translation studies.
\end{abstract}

\section{Keywords}

African literature, China-Africa relations, Chinese, diplomacy, translation, soft power

\section{Introduction: Contemporary Sino-African relations and the concept of soft power}

While the history of relations between China and many African countries is long and complex, it is since the turn of the twenty-first century that China's presence in Africa has intensified and become considerably more visible. The year 2000 marked the founding of the Forum on China-Africa Cooperation (FOCAC), an initiative which describes itself as a 'platform [...] for collective consultation and dialogue and a cooperation mechanism between the developing countries, which falls into the category of South-South cooperation' (Ministry of Foreign Affairs of the PRC 2004a). As of 2018, the current FOCAC members are China, the Commission of the African Union, and fifty-three African states. FOCAC Conferences are held every three years, and an extensive Action Plan for political, economic, and cultural cooperation is agreed at each one. ${ }^{1}$ The fanfare that surrounded the 2006 event in Beijing drew the eyes of the world to China-Africa cooperation, and led to increased media focus on

\footnotetext{
${ }^{1}$ The plans also cover social development cooperation and security cooperation. English versions of the plans can be viewed on the FOCAC website (www.focac.org/eng/).
} 
China's presence in Africa. This was the same year in which China published a white paper on its African foreign policy, stressing 'sincerity, friendship and equality [..] mutual benefit, reciprocity and common prosperity [...] mutual support [...] learning from each other and seeking common development' (People's Daily Online 2006). In many respects this discourse of friendship and mutual respect is one that deliberately sets itself in opposition to the way in which the West engaged with Africa - and, in the view of many, continues to engage - on a much more hierarchical basis.

Most academic research in this area has focussed on the economic activities that form the core part of the China-Africa relationship, whether in the form of trade, aid, or investment. Another significant aspect of China-Africa relations, however, concerns cultural cooperation, a domain which encompasses cultural events and visits as well as people-to-people exchanges and language learning opportunities. A number of studies have been devoted to the most prominent of these types of cooperation, the Confucius Institutes (see Gil 2017, King 2013; 2017). Other topics which have been the focus of article-length studies include cultural diplomacy (Liu 2008), cultural and sports exchanges in historical contexts (Lefkowitz 2017, Shuman 2017), cultural cooperation in FOCAC Action Plans (Batchelor 2017), and Chinese book donations to Africa (Gilbert 2017). 2018 also saw the launch of a curated dataset on cultural institutes in Africa, encompassing Chinese as well as other actors (Nederhood 2018). Many of these studies link cultural cooperation and the notion of soft power, a concept first outlined by Joseph Nye in relation to American foreign policy and subsequently enthusiastically adopted and significantly adapted by Chinese academics and policymakers. ${ }^{2}$ Defined in basic terms as 'getting others to want the outcomes that you want' (Nye 2004, 5), Chinese policymakers typically envisage soft power as a process through which a 'benign

\footnotetext{
${ }^{2}$ For an overview of the history of Chinese adoption of the term, see Li and Roenning (2013). On the extent to which the term has penetrated Chinese academic and policymaking, see Breslin (2011).
} 
and acceptable image of China' (Gil 2017, 29) can be presented to the world. Chinese scholars tend to adopt a broad understanding of what they term 'soft power-based foreign policies', as Ding $(2008,195)$ explains:

soft power-based foreign policies may include, but not limited to [sic], economic cooperation based on mutual benefits, attraction-oriented cultural and educational exchange; regular high-level official visit between two countries; active involvements in multilateral activities of international regimes; efficient campaign of public relations over sensitive global issues, etc.

In this article, I shall turn to a hitherto unexplored aspect of cultural cooperation, namely literary translation, with the goal of exploring any connections between literary translation activities and China's efforts to exert soft power. In translation studies, a number of theorists have explored connections between literary translation and power dynamics, and this article may be seen as an effort to build on and extend those enquiries. ${ }^{3}$ While connections between literary translation and power have been investigated through a variety of methods including textual analysis, paratextual analysis or the statistical tracking of translation flow, in this article I shall focus primarily on processes of translation selection and dissemination, drawing on a variety of sociological methods in order to shed light on the 'stakes and functions of translations, their agencies and agents, the space in which they are situated and the constraints, both political and economic, that circumscribe them' (Heilbron and Sapiro 2007, 95).

The article will first present the general translation selection patterns that appear to govern the translation of African literature into Chinese. It will then explore the translations that form exceptions to these patterns, investigating how the translations came about and

\footnotetext{
${ }^{3}$ See, for example, Jacquemond (1992), Venuti (1995), Lambert (1995) and Casanova (2007).
} 
evaluating their political functions. Finally, the article will discuss the ways in which these particular translations can be related to the notion of soft power, interrogating the potential usefulness of soft power as a concept for translation studies in the process.

\section{Methodology}

In order to explore the translation selection patterns governing the translation of African literature into Chinese, we need first to define what we mean by 'African' literature. As I observe in Decolonizing Translation (Batchelor 2009, 8-9), the issue of what should be considered 'African' literature is a contentious one. In this article, I adopt the same nationality-based criterion as I used in that earlier work, considering as 'African' any literature written by authors from African countries, even if the literary work in question does not deal with what Bandia $(2008,13)$ terms 'the African experience'. As this study deals with translation into Chinese, I consider as 'African' any country which official Chinese sources themselves consider to be 'African' (see, for example, Ministry of Foreign Affairs of the PRC 2004b). This therefore encompasses all countries located on the continent of Africa as well as the islands around the continent, most notably for this study the Seychelles.

'Literature' is another term whose parameters are invariably open to debate. In our research for this article, we took a broad view of what might be included under the term, gathering data about all types of literary works, including biographies, memoirs, and children's literature. For reasons of space, however, the analysis presented here limits itself to novels, short story collections and poetry for adults, and encompasses only literature published as books rather than in journals or magazines. As our goal was to assess the role played by literary translation in contemporary Sino-African relations, we limited the corpus to translations published between 2000 and 2015, the latter being the year in which we carried out our survey, and the former the date that corresponds to the founding of the FOCAC and 
the intensification of China-Africa relations. Chinese translations of African literature were identified using the Chinese search engine Baidu (百度), the catalogues of the three largest libraries in China, the National Library of China, Shanghai Library and Nanjing Library, the social networking site Douban (豆瓣), and the second-hand online bookseller Beijing Ancient Castle Books (孔夫子旧书网). All possible permutations of generic labels were used as search terms (e.g. 非洲作家 [African authors], 非洲文学 [African literature], 非洲诗歌 [African poetry], 非洲小说 [African novel], 非洲文学中文译本 [African Writing in Chinese Translation], 肯尼亚文学 [Kenyan literature], 尼日利亚作家 [Nigerian authors]). We also searched for specific African authors by name, using the 'Africa's 100 Best Books' list compiled by the Zimbabwe International Book Fair as a starting point (see Columbia University Libraries 2018 for further details). News reports of China-Africa cooperation were also scanned for relevant information and findings were verified using the Chinese search engines and catalogues noted above (this was particularly relevant for the translations of Henri Djombo's novels and for the poetry anthology No Serenity Here, both of which will be analysed below). Once the data had been identified, a preliminary analysis was carried out in order to establish a hypothesis about the principles governing translation selection and to identify apparent exceptions to that hypothesis. Face-to-face interviews were carried out in China with twenty-one Chinese publishers, including all of those publishing houses whose publications did not fit the dominant selection pattern. A face-to-face interview was also carried out with the commissioner of the poetry anthology, No Serenity Here, and questions were put by email to Philippe le Gall (see below for further discussion). The interviews were semi-structured, the specific questions being tailored to each publishing house with the aim of assessing the validity of our general hypothesis and gaining further information about translation selection processes. The political backgrounds to the translations which did not fit 
the dominant selection pattern were further investigated using a variety of secondary literature, journalistic reports, and internet searches.

\section{African literature translated into Chinese: translation selection patterns}

Through the methods outlined above, we identified 68 books of fiction by African authors published in Chinese translation in China between 2000-2015. With the exception of one poetry anthology (to which I shall return below), all of the books are by a single author, and these 67 books are by 26 different authors. The vast majority of the authors are internationally acclaimed writers of literary fiction whose books have had a high degree of commercial success on a global stage. In the case of the nine authors who saw more than one of their books published in Chinese translation during this period, for example, all except one are winners of prestigious international prizes. They are the four African winners of the Nobel Prize in Literature, J. M. Coetzee (18 books), Naguib Mahfouz (9 books), Nadine Gordimer (5 books) and Wole Soyinka (3 books); Man Booker International Prize winner Chinua Achebe (6 books); Booker Prize winner Ben Okri (3 books); Orange Broadband Prize for Fiction winner Chimamanda Ngozi Adichie (2 books); and French Chevalier de l'Ordre des Arts et des Lettres Gamal El'Ghitani (2 books). ${ }^{4}$ The only writer who has had more than one book published in Chinese translation and who is not an internationally acclaimed author is the Congolese writer Henri Djombo. His case is important to our study and we will return to it below.

The 18 authors who have had only one book published in Chinese during the years 20002015 are also for the most part writers of literary fiction who have been successful on an international level: they include Goncourt Prize winners Ahmadou Kourouma, René Maran

\footnotetext{
${ }^{4}$ The prizes that are cited here and in the following paragraph are intended to serve as an indicator of the author's success on an international level, rather than to posit a direct link between the award of the particular prize in question and the decision to publish their work in Chinese translation.
} 
and Tahar Ben Jelloun; winner of the Neustadt International Prize for Literature, Assia Djebar; Guardian First Book Award winner Petina Gappah; Chevalier de l'Ordre des Arts et des Lettres Mustapha Tlili, and Park Kyong-ni Prize winner Ngugi wa Thiong'o. The list of translated books also encompasses the bestselling book Yacoubian Building by Egyptian writer Alaa Al Aswany and one work of popular fiction by South African author Sheila Kohler, Cracks, both of which have been made into films.

The selection of African literature for translation into Chinese would thus seem to be predicated primarily on markers of status and international popularity, and in this sense is consistent with Shuyu Kong's (2005) observation that 'market forces have now become the dominant element in literary production' (9) in China, with publishing houses - whether state-owned or not - 'aware of the [...] need to earn profits even from literary titles' (126). The general principle of using international success to determine which authors to select for translation was also confirmed in an interview with a representative from Yilin Publishing House in 2015, in which the interviewee identified 'prizes, best-selling status, internet ranking and newspaper reviews' as the common standards used for selecting foreign works for translation and publication. ${ }^{5}$ Similar criteria were also cited by representatives from Beijing Foreign Languages Press, Beijing Foreign Language Teaching and Research Press, Chongqing Publishing House, Chongqing University Publishing House, Guangxi Normal University Publishing House, Hunan Literature and Art Publishing House, Shanghai Literature and Art Publishing House, and Shanghai Translation Publishing House, all of whom were interviewed in 2015. Several of the publishers used this as a means to explain the small proportion of African literary works on their lists, indicating that the sales potential for African literature in China was considered to be low overall. The educational publisher

\footnotetext{
${ }^{5}$ This and all subsequent quotations from interviews were translated from Chinese into English by Sarah Fang Tang.
} 
Shanghai East China Normal University Publishing House (interviewed the same year) presented a slight variation on these criteria, stating that they take into consideration the potential for a book to serve as a teaching and learning resource. ${ }^{6}$

However, there are a handful of translations which do not fit this general pattern of commercial motivation, and which seem instead to be evidence of the 'lingering government influence' (Kong 2005, 9) that is still 'readily apparent' (Kong 2005, 9) in literary production in China. These politically influenced translations would appear to have two slightly different types of motivations, as I shall outline below.

\section{Case Study 1: Translations of works by Henri Djombo and Muammar Gadaffi}

\section{Henri Djombo}

To explore the first of these motives, let us return to the author who is the only one to have had more than one book published in Chinese without himself having attained international recognition for his literary output, Henri Djombo. From Congo Brazzaville, Djombo is currently serving as Minister of State for Agriculture, having been Minister of Forestry, Environment and Sustainable Development from 1997-2016, and Minister of Water and Forests prior to that. Djombo has written several plays and five novels, ${ }^{7}$ two of which, $L a$ traversée and Sur la braise, were published in Chinese translation in 2012. The same year, at a book launch in Brazzaville for two of Djombo's other novels, the co-ordinator of the Chinese Committee of Translators, Monique Zhang Yongping, reportedly announced that Le cri de la forêt would be translated into Chinese (see Biozi Kiminou 2012), although it does not yet seem to have been published.

\footnotetext{
${ }^{6}$ The representative from this publishing house explained that Alaa Al Aswany's The Yacoubian Building was selected on the basis of its potential to serve as a learning resource about the history of Egypt.

${ }^{7}$ According to the site Babelio, Djombo is author of more than ten novels, but I have not been able to find bibliographic records for all of these. https://www.babelio.com/auteur/Henri-Djombo/309733
} 
Unlike the majority of other works translated into Chinese, Djombo's novels have not found international acclaim and have not been translated into any other languages; furthermore, with the exception of Sur la braise, which was published by the Parisian publishing house L'Harmattan, Djombo's novels were published by the Congolese publishing house Hémar, or jointly by Hémar and Présence Africaine. Once again, this stands in contrast with the other Francophone novels translated into Chinese, all of which were published in Paris, a number of them by the prestigious publishing house Editions $d u$ Seuil.

The basic facts surrounding Djombo's works thus strongly suggest that a motive other than commercial gain is at play in the case of these translations, and this hypothesis is borne out by the interview that we conducted with a representative of the Chinese publishers of Sur la braise and La traversée, the Beijing-based China Translation and Publishing Corporation. The representative stated that the books were 'allocated by the China Publishing Group to which our publisher belongs. Sometimes we will publish books for reasons of political diplomacy'. When asked for further details, the interviewee suggested that '[a]s far as I know, the Fifth Ministerial Meeting of the China-Africa Forum was held in Beijing on $19^{\text {th }}$ July 2012. To promote friendship between China and Africa, the books of the Cultural Minister were translated and published'.

This rather vague account suggests that the translation of Djombo's works functioned to promote China-Africa friendship in general, indicating perhaps that Djombo's novels thus served in a symbolic way as 'African' culture, and that the translations into Chinese were intended as a sign that the Chinese appreciate and value African culture. However, when we probe a little further, the connection between Djombo and Chinese government interests reveals itself to be much more direct, and the translations take on a potentially problematic hue. 
As noted above, Djombo is a senior politician who served as Minister of Forestry for almost twenty years (he was never Cultural Minister as the publishing house interviewee suggests). In that role, Djombo oversaw the protection of Congo's forests and the granting of logging concessions to timber companies. The Chinese have significant interests in Congolese timber: according to Global Forest Watch (2018), eight companies registered in China currently possess logging concessions in the Republic of Congo, and China is by far the largest export market for Congolese timber (Lawson 2014). While the Forest Stewardship Council website hosts a positive, near-eulogistic summary of Djombo's career and activities (see Forest Stewardship Council 2014), other sources have linked Djombo or his office to corrupt concession allocation processes and illegal logging, including in connection with Chinese companies and China (see, in particular, Cannon 2016, Lawson 2014, Stiles 2014).

In their book-length study La Chinafrique, two leading journalists, Serge Michel and Michel Beuret (2008) posit a direct link between Djombo and one of the Chinese companies, SinoCongo Forêt (Sicofor), stating that Djombo is a major shareholder in the company, and suggesting that 'cela explique sans doute comment, à la stupeur des ONG européennes chargés de surveiller la forêt congolaise, Sicofor a pu reprendre les actifs de Man Fai Tai sans qu'il soient soumis à un appel d'offres' (95) [that undoubtedly explains how, to the amazement of the European NGOs tasked with monitoring the Congolese forest, Sicofor was able to take over the assets of Man Fai Tai [another Chinese logging company] without any tendering process]. ${ }^{8}$

Djombo has categorically denied that he is a shareholder in Sicofor, and accuses Western NGOs of bias against him and the Chinese (Lubabu, 2008). Nevertheless, it is not difficult to find news reports attesting to Djombo's friendly relations with the Chinese, including those

\footnotetext{
${ }^{8}$ Congolese activist Mingwa Biango (2010) also claims that Djombo is a shareholder in Sicofor, but it is not clear whether this information is taken from the same (undocumented) source as Michel and Beuret's claim, or whether it can serve as independent corroboration of their account.
} 
involved in the timber industry (see, for example, Congo-SiteOfficiel 2010; SEFYD 2018;

Xinhua 2011; Xinhua 2012). Furthermore, few would dispute the view that having high-level political friends in Congo is helpful for Chinese individuals and corporations with an interest in timber exporting or related businesses, particularly when one of those senior politicians holds 'wide discretionary powers with regard to allocation of rights to harvest' (Lawson $2014,10)$, as was the case with Djombo. In this context, the translations of Djombo's novels into Chinese need to be seen not so much as a symbol of China-Africa friendship as a means through which the Chinese can affirm their friendship with the Minister of Forestry directly, using the translations to deepen the Minister's inclination to look favourably on Congo-China trade in this key domain. In this sense, these literary translations fit with the paradigm of 'letting culture be a bridge for business' (Liu 2008, 17), which Liu $(2008,17)$ identifies as a key motivation for Chinese cultural diplomacy since the 1990s. In the case of the third of Djombo's novels to be translated into Chinese, Le Cri de la forêt, this gives rise to a contradictory situation: while the novel aims to promote awareness of the importance of preserving Congo's forests, at least some of the Chinese companies to which Djombo has granted logging rights have been shown to have violated Congolese forestry laws (see Cannon 2016, AJDHPE 2012), without ever having had to face effective sanctions (Lawson 2014).$^{9}$

\section{Muammar Gadaffi and two other Libyan authors}

Djombo is not the only senior politician to feature on the list of literary translations by African authors into Chinese. Another book which does not fit the pattern of commercial motivations and which was identified through our survey is the short story collection by former Libyan president, Muammar Gadaffi. First published in Libya as separate collections

\footnotetext{
${ }^{9}$ We should note that European companies involved in the timber trade have also been open to criticism (see, for example, Cannon 2016; Rowe 2013; World Wildlife Fund 2005).
} 
of stories and essays in 1993 and 1995 (Salinger 1999, xxviii), the material was published in English translation in the UK in 1999 under the title Escape to Hell and other Stories. The book did not become widely known and its literary merits are dubitable (a review in The Guardian once described it as 'undeniably awful' (Kalder 2010)). In 2001, a Chinese translation of the essays was published by Changjiang Literature and Art Publishing House. ${ }^{10}$ This was one of three translations of works by Libyan authors carried out between 2000 and 2002, the others being the trilogy Gardens of the Night by Ahmed Fagih and 往事依依 [Reliance on the Past], a collection of short stories by Ramadan Abdallah Bukheit. ${ }^{11}$ Although Fagih is a successful author within the Arab world, ${ }^{12}$ and has also seen a number of his books translated into English, albeit by small presses rather than mainstream publishing houses, ${ }^{13}$ none of these Libyan authors have known international success at a level comparable to the majority of other authors translated into Chinese. It is also striking that the dates of publication of Chinese translations by Libyan authors are closely clustered together, and that all were published by the same publishing house. No other books by Libyan authors were published in Chinese translation between 2000 and 2015. All of these facts suggest that motivations other than the straightforwardly commercial were in play when these works were translated into Chinese. In an interview, the representative from the publishing house in question was able to shed only limited light on the situation, as she was not in post at the time of the publications. Her understanding was that the three books by the Libyan authors were suggested by the state-owned China Publishing Group Corporation; ${ }^{14}$ she also indicated that

\footnotetext{
10 The Chinese version was translated from the Arabic by Professor Rongjian Li, an expert in Arabic language and culture.

${ }^{11}$ Chorin's (2015) summary of Bukheit's output indicates that his stories were published in magazines rather than as books, although the Douban website's introduction to the Chinese translation states that the collection of stories that corresponds to the Chinese version was published in Arabic in 1996.

${ }^{12}$ Gardens of the Night won the Beirut Book Fair prize in 1991 (Chorin 2015).

${ }^{13}$ These include Quartet, Paul Kegan International, and DARF. For more information on Fagih, see Chorin 2015.

${ }^{14}$ For an overview of publishing structures in China, see Sun, Yang and Mao 2009.
} 
cultural diplomacy had almost certainly played a role in the decision, as is often the case for their publishing activities more broadly.

While information about the history of China-Libya relations is rather scant, a brief statement by the Chinese Foreign Ministry dated October 10, 2006 notes: 'In 2001, a program on implementation of cultural and information cooperation from 2001 to 2004 was signed' (Chinese Foreign Ministry 2006). Further information about China-Libya relations during this period can be found in Ronald Bruce St John (2014), and shows that both the Chinese foreign minister and the Chinese president made official visits to Libya during the years that coincide with the publication of these three Libyan books:

In January 2001, the Chinese foreign minister, Tang Jiaxuan, made an official visit to Libya, signing agreements on cultural and information cooperation, and in April 2002, the Chinese president, Jiang Zemin, also visited Libya. In the course of the first visit of a Chinese president to Libya, the two states concluded an agreement opening Libya's hydrocarbon sector to Chinese firms and a multimillion-dollar deal for the China Railway Construction Corporation (CRCC) to build part of a new rail transportation network. (St John 2014, 76)

While St John's account stresses the trade deals that were agreed after Jiang Zemin's visit, the diplomatic importance of the earlier visit by Tang Jiaxuan should not be underestimated. A report dated 12 January 2001, which is still available on the Ministry of Foreign Affairs of the People's Republic of China website, records a meeting between Tang Jiaxuan and Gadaffi which took place on 10 January 2001. In addition to affirmations of the importance of bilateral relations between China and Libya, the report states that 'Gadaffi also briefed Tang on the African Union that Libya is actively working to put in place' (Ministry of Foreign Affairs of the PRC 2001), and that Tang 'briefed Gadaffi on the Forum on Sino-African Cooperation, Ministerial Conference, Beijing, 2000' (ibid). This report thus suggests that the 
special attention paid by China to Gadaffi in 2000-2002 may have been strategically connected with Jiang Zemin's plans to build up Sino-African cooperation, allowing him to ensure that relations with the key mover behind the efforts to establish an African Union were favourable. ${ }^{15}$ The timeframe for the publication of the three Libyan translations would tie in with these visits, making it likely that the translations served in some way to cultivate highlevel friendships. The 2000 translation of Ahmed Fagih's trilogy follows shortly after the 9 September 1999 Sirte Declaration calling for the establishment of the African Union and shortly before the Chinese foreign minister's visit to Libya; the 2001 translation of Gadaffi's own book comes soon after the meeting between Tang Jiaxuan and Gadaffi in Libya in January 2001; and the 2002 translation of Bukheit's short stories comes in the same year as the Chinese president's visit to Libya. ${ }^{16}$

Although it is difficult to prove beyond doubt that there is a connection between the Libyan translations and Chinese state diplomacy, there are nevertheless a few significant further indicators that lend support to this hypothesis. Firstly, according to a report by China's Forbidden News (2011), a Chinese interviewer who interviewed Gadaffi on a CCP-backed TV channel in 2010 is said to have 'praised Gadaffi as a very poetic writer': ${ }^{17}$ this appears to be an allusion to Gadaffi's short stories and shows that Chinese awareness of Gadaffi's literary output was used on at least one occasion to flatter the Libyan leader. Secondly, we know of another case of a book by a senior African politician that appears to have been

\footnotetext{
${ }^{15}$ For more information on the formation of the African Union and the role played by Gadaffi, see Bedjaoui (2012) or Maluwa (2012). We should also note, however, that the way in which cooperation between China and the African Union has played out has been complex and contradictory: Ikome $(2010,208)$ reports for example that 'the FOCAC meeting in Beijing in 2006 registered deliberate and conscious efforts by both some African states and China to sideline the African Union during the meeting', and suggests that this 'clearly revealed the tensions between the rhetoric of multilateralism and the practical disposition to bilaterialism in Africa's engagement with China'.

${ }^{16}$ It is possible that the works by Gadaffi and Bukheit formed part of the cultural cooperation agreement signed in 2001, but I have not been able to obtain a copy of this document.

${ }^{17}$ The interview appears in a YouTube video posted by China's Forbidden News. The video was made in October 2011 to counter the Chinese Communist Party's assertion that it had never been friends with Gadaffi. See China's Forbidden News 2011. The quotation is taken from the English subtitles.
} 
translated into Chinese in circumstances which mirror those of the Djombo and Gadaffi/Libyan translations. This is the non-fiction work Un destin pour l'Afrique by Abdoulaye Wade, president of Senegal from 2000-2012. First published in 1989 and republished in 2006 by the Paris-based publisher, Michel Lafon, a Chinese edition was published by Beijing Xinhua Press, a state-owned publishing house for politics and international relations, in 2008. As with the Libyan books, the timing of this publication strongly suggests a link between the translation and China's diplomatic efforts: Senegal restored political relations with the People's Republic of China in October 2005, and Wade visited China and met with the Chinese premier, Hu Jintao, on 22 June 2006 (Ministry of Foreign Affairs of the PRC 2006), subsequently meeting him again privately while in Berlin for the G8 meeting in June 2007 (Embassy of the People's Republic of China in the Republic of Senegal 2007; Wade 2008).

\section{Case Study 2: No Serenity Here and works by Phillippe Le Gall: creating a positive image of Sino-African relations}

In the first part of this article, we have considered five of the translations which do not fit the pattern of selection of the basis of international success. A further four publications merit further scrutiny for the same reason: they are the poetry anthology No Serenity Here, and three books by the Ambassador of the Seychelles to China from 2007 to 2015, Philippe Le Gall. The most striking thing about all of these books is that they cannot be traced back to a source text published outside China, as we will see below.

\section{No Serenity Here}

The No Serenity Here poetry anthology was edited by the South African writer and performance poet Phillippa Yaa de Villiers, together with the German freelance project manager Isabel Ferrin-Aguirre and the Chinese poet Xiao Kaiyu. It was published in Beijing 
by New Knowledge Publishing House in 2010, and draws together poems by African authors previously published in various countries in magazines, as part of other anthologies, or on the internet. The book is presented in bilingual format, with the original language poem and the Chinese translation laid out on facing pages. The anthology contains a preface by de Villiers in which she underlines the cultural wealth contained in the volume and explains that the anthology was created 'in a desire to offer an experience of Africa through poetry to the Chinese people' (de Villiers 2010, iii-iv). There is also an introduction by Xiao Kaiyu, which similarly lauds the value of the poetry and stresses the benefits for Chinese readers in encountering African poetry: 'Africa is a part of the contemporary world with its imperiled [sic] environment, enigmatic relations, and its frayed psychology. No matter how innocent or unaffected, Africa is no exception to this. From the point of view of poetry per se, these works from an utterly different literary tradition are deeply inspiring' (Kaiyu 2010, x-xi). The paratexts of the anthology thus position it as a work which serves the cause of China-Africa relations by enhancing Chinese people's appreciation of African cultures.

According to Kaiyu's (2010, x) introduction, it was one man's own appreciation of African culture that led to the commissioning of the volume: 'Renowned artist Hu Xiangcheng is profoundly drawn to the literary, as well as the visual, arts. At an early age, he spent some time in Africa and to this day has a deep longing for it'. In an interview that we conducted with Hu Xiangcheng in 2015, Hu confirmed this and provided a more detailed account of the motivations behind the volume:

In 2010, I was the Artistic Director in Shanghai Expo Africa Joint Pavilion. I was planning to hold an art exhibition themed as 'African light'. But time is not enough and the government funding is not sufficient to finish it. Thus I planned to publish a poetry book of Africa. Poetry is an important artistic expression in African literature. I have been in Africa for three years. I am very interested in 
African culture and arts and as a witness; I also had a direct impression of African literature's influence on world literature. But the influence of African literature on China is not direct but through European perceptions. Thus we consider it significant to get the poetry book published in order to have a flavour of African literature from first-hand experience. [...] In Shanghai Expo, as a gift the poetry book was presented to the ambassadors of African countries. Also a poem reading ceremony was held; the atmosphere is quite good. The illustrations in the poetry book were drawn by me.

This account both confirms and counters the idea that the poetry anthology is intended to enhance Chinese appreciation of African culture. Confirmation is found in Hu's description of his own love of African culture and his desire to offer Chinese audiences a 'first-hand' 'flavour of African literature'. At the same time, Hu's description of the use to which the volume was put at the Shanghai Expo suggests that another motivation was at play in the production of the volume: rather than having a Chinese audience, the primary audience for the book in the context of the Shanghai Expo was African ambassadors. Our interview with New Knowledge Publishing House, conducted in 2015, suggests that this high-level political African audience was in fact the primary audience for the anthology:

Before 2010 Shanghai Expo, [Hu Xiangcheng] funded this book's publishing, which helps promote the friendliness between China and Africa. [...] Shanghai Expo is such a good chance to show the world Sino-African friendliness. In Shanghai Expo, the Foreign Ministry held a series of initiatives. More than 200 African ambassadors took part in those initiatives and the book was presented as a gift for them to show our special attention to African culture. After that we held the ministers' talks between China and Africa, and this book also served as the gift for them. 
In the interview, the publishers also acknowledge that the expensive nature of the book mean that it has found few purchasers, and in response to a specific question about the target readers for the book, state:

There are three kinds of target readers for this book. The first is for political officials. The second is academic researchers. The third will be poem-lovers domestically. But the target readers are quite limited. Thus the book is not selling well and we can't make profits out of it.

While Chinese readers are thus certainly not excluded as a potential target audience for this translation, it would appear that the primary audience was indeed African diplomats. The book can thus be argued to have served two principal functions, both of them political: firstly, through its distribution to African ambassadors and ministers, it served the purpose of affirming the importance of China-Africa relations to African politicians; secondly, however, as part of the showcasing of China's friendship with Africa that took place through Shanghai Expo and more specifically through the construction of the Africa Joint Pavilion, the book potentially also served as evidence of China-Africa friendship for a wider global audience. ${ }^{18}$

\section{Phillippe le Gall}

The personal involvement of Hu Xiangcheng in the production of No Serenity Here has parallels with the way in which works by Philippe le Gall were written and published. Chinese translations of three works by Le Gall appeared in 2012, 2013 and 2014, and in an interview conducted by email in 2015, Le Gall indicated that his books are motivated by a personal appreciation of the other side's culture and a desire to further enhance China-Africa friendship. He comments:

\footnotetext{
${ }^{18}$ For an example of how the Africa Joint Pavilion is held up as an example of China's respect for Africa, see Zhang 2010.
} 
I write these books as a Seychellois Ambassador and as an African Ambassador. I am perceived as such in the context of the China-Africa Forum of Cooperation and it is understood that beyond the specific content of each book this is my contribution as an African writer to the strengthening of the relations of friendship and cooperation between China and Africa.

Although Le Gall writes in French, two of his books, the novel The Path to Venice (2012) and the short story collection Together Forever (2013) have only been published in Chinese translation, the source texts themselves remaining unpublished. A second novel, The Jewels of the Empress (2014), was published in French by a Chinese publisher in a limited print run of 200 copies in the same year that the more professionally produced Chinese translation was published by Shanghai Translation Publishing House. In the interview, Le Gall also emphasises his appreciation of Chinese culture and suggests that the fact that he is 'not trying to have [his] books published in French or English first... but straight in the Chinese version' is a 'way of showing how much [he] feel[s] indebted to Chinese culture and to its so often under-estimated contribution to the Universal Civilization'. In Le Gall's view, then, his writing activities go hand-in-hand with his diplomatic work and serve primarily to enhance China-Africa relations.

While Le Gall emphasises the links between his books and an affirmation of Chinese culture, a China Daily report on a speech given by Le Gall in Beijing in 2012 suggests that the translations also benefit Le Gall's own country, the Seychelles. The report indicates that 'the ambassador uses cultural exchange to raise the visibility of his nation' (China Daily 2012), and aligns his writing activities with his promotion of the Seychelles as a destination for Chinese tourists. In this scenario, then, literary translation is used to promote friendly relations between China and the Seychelles to the benefit of both sides. 


\section{Literary translation and soft power: theoretical reflections}

The non-commercially motivated translations discussed above have been shown to have been produced for a variety of political motives. These range from sweetening relations with high level politicians for potential political or economic gain, to serving the cause of China-Africa relations with potential benefits for the global image of China or for particular African countries. In general terms, the politically-motivated translations that were initiated by the Chinese side can be connected with Chinese efforts to build up a positive, non-threatening image of the country or to seek to influence others to act in Chinese interests without using coercion, both of which fall into the category of soft power policies as defined by Chinese policymakers..

If we are to understand the connection between literary translation and soft power more fully, however, it is important to interrogate the mechanisms through which literary translation can be said to 'become' or 'produce' soft power. This is an endeavour which is undoubtedly complicated by the inflections in definitions of soft power to which I referred in the introduction. The fluidity of these definitions extends well beyond the adaptations of Nye's term by Chinese policy makers, to the extent that some scholars have argued that soft power needs to be reconceptualised (Rothman 2011) or 'disaggregate[d] ... into separate "soft powers"" (Hall 2010, 190-1). To avoid becoming mired in discussions of the variations and usefulness of the concept of soft power itself (discussions which, as Hall $(2010,191)$ observes, would result in 'a project of several volumes'), I shall base my interrogation on Nye's (2004) original theorisation of soft power. Readers should nevertheless bear in mind that the theoretical discussion of translation and soft power that follows may well need to be nuanced according to the culturally situated and diverse definitions of soft power that are currently in use. 
The particular aspects of Nye's theorisation on which I would like to focus are his distinctions between resources, power, and diplomacy. Although Nye frequently conflates the first two of these terms, speaking of 'soft power resources' $(2004,8)$ and explaining in a rather tautological manner that 'soft power is attractive power ... soft-power resources are the assets that produce such attraction' $(2004,6)$, his emphasis on the role played by context in determining whether or not an asset actually exerts power allows us to tease them apart in a way that allows for greater theoretical clarity. For example, with regard to what is often considered one of America's key soft power resources, Hollywood, Nye $(2008,95)$ suggests that 'exporting Hollywood films full of nudity and violence to conservative Muslim countries may produce repulsion rather than soft power'. In this analysis, Hollywood can be considered in basic terms to be a resource; in certain contexts - but not in others - it is also a soft power resource. The mobilisation of a soft power resource is carried out in Nye's $(2008,95)$ theorisation through public diplomacy:

In international politics, the resources that produce soft power arise in large part from the values an organization or country expresses in its culture, in the examples it sets by its internal practices and policies, and in the way it handles its relations with others. Public diplomacy is an instrument that governments use to mobilize these resources to communicate with and attract the publics of other countries, rather than merely their governments. Public diplomacy tries to attract by drawing attention to these potential resources through broadcasting, subsidizing cultural exports, arranging exchanges, and so forth.

On the basis of these statements, it is possible to outline a series of definitions of our own which will prove useful for theorising the connections between soft power and literary translation:

- $\quad$ a resource $=$ a thing, idea, or way of behaving that may or may not attract others 
- $\quad$ a soft power resource $=$ a resource that has the ability to attract others; note that at this stage, the 'others' must already be defined

- $\quad$ public diplomacy $=$ the process through which the defined 'others' are made aware of the soft power resource

Now that we have broken down the exertion (or, more precisely, the attempted exertion) of soft power into these three separate stages, it is possible to see a number of specific points at which literary translation - or indeed the translation of other kinds of material - can play a role:

1) In the creation of a resource ${ }^{19}$

2) In the process of making a given resource into soft power, or in other words, turning the raw resource into a thing or idea which, in someone's estimation, will be attractive to specific others

3) In the process of telling others about the soft power resource (i.e. through diplomacy)

To illustrate how a translation project might play into these processes, let us return to the case of the poetry anthology, No Serenity Here. In the sense that this project entails the creation of a cultural artefact, it corresponds to the first process outlined above (creation of a resource). As a resource, the anthology possesses two sets of characteristics, each of which have the potential to be exploited in the second stage of the process, whereby the resource is turned into a soft power resource. Firstly, as something which gives a flavour of the variety and richness of African poetry in a language which a particular type of audience (Chinese) can understand, it has the potential to become a soft power resource that increases the

\footnotetext{
${ }^{19}$ While Breslin (2011) disputes the understanding that soft power is 'something that needs to be actively promoted' (7), preferring instead to understand it as 'the latent power of attraction' (8), I would argue that Nye's conceptualisation of soft power does allow for the deliberate, conscious creation of resources which have the potential to become soft power resources. For example, in his discussion of the soft power of the Soviet Union, Nye $(2004,74)$ points to the large sums spent by the USSR on ballet companies and symphony orchestras as well as its investments in sport.
} 
attractiveness of Africa in the eyes of Chinese people. In this scenario, the resource could thus become an African soft power resource. ${ }^{20}$ Secondly, as something which displays cultural exchange between China and Africa, it speaks to the third category of potential soft power resource identified by Nye $(2004,8)$, namely 'the way [an organization or country] handles its relations with others'. In this scenario, it is the Chinese interest in the African poems rather than the poems themselves that are paramount, and the anthology has the potential to become a Chinese soft power resource displaying Chinese friendship and cooperation. As we saw in the earlier part of this paper, the paratexts of the anthology anticipate and to a certain degree attempt to achieve the first of these scenarios, emphasising the value of the anthology as something which displays African culture to the Chinese. In terms of how the resource was mobilised, however (the third process), it is clear that the anthology ended up serving primarily as a Chinese soft power resource, displaying Chinese appreciation of African cultures to an African (and potentially also a global) audience. The case of this anthology thus underlines the indispensability of the third process to the transformation of literary translations into soft power: the fact that effort and financial resources were put into making the anthology available to ministers and ambassadors at Shanghai Expo rather than into making the book affordable and discoverable by the Chinese reading public means that the anthology functioned primarily as a Chinese rather than an African soft power resource. Furthermore, the act of distributing the translation to the ambassadors and ministers itself becomes another Chinese soft power resource, the gift and the ceremonies that accompanied the gift-giving conveying China's respectful treatment of its African partners.

\footnotetext{
${ }^{20}$ Indices of soft power are usually calculated for individual nations, rather than for continents. However, in my view there is a case for exploring the soft power of larger groupings, particularly where these are commonly treated as distinct entities by the media. 'Africa' represents one such case in point, as does 'Europe', particularly from the perspective of current UK politics.
} 


\section{Conclusion}

The cases analysed in this article show that literary translation is being used strategically by the Chinese in connection with their efforts to increase their soft power, particularly in Africa. As small-scale projects with limited dissemination, the primary target of influence would appear to be African policymakers and diplomats rather than the broader African public. The translations of Le Gall's works represent an interesting twist on this scenario, in the sense that they are produced by someone who is considered to belong to the African side, rather than the Chinese, and carry clear soft power benefits for Le Gall's own country as well as for China.

As I have shown through my analysis of the creation and dissemination of the poetry anthology No Serenity Here, the concept of soft power is useful for understanding the political purposes that may be served by translation. This is particularly true if the process through which soft power is produced is broken down into stages, with attention paid not only to the translation product but also to the circumstances in which the translation was commissioned or selected, and in particular the ways in which it was disseminated (or in which it failed to be disseminated). A fuller investigation of the connections between soft power and translation in the China-Africa context might usefully extend beyond literary translation and explore the creation and translation of other types of books and book-related products, ranging from political and historical texts to documentaries and popular television series. Such a study would give full consideration to the flow of cultural products in both directions, rather than limiting itself to the translation of African literature into Chinese as this article has done. It might also incorporate detailed analysis of the translated products themselves, with a view to understanding the ways in which soft power plays out at the level of the text itself. Ideally, research into production, selection and dissemination would be complemented by research into reception, thereby opening up discussions of the actual - as 
opposed to the potential - exertion of soft power. Given the complex nature of soft power, however, investigating the actual soft power exerted by any particular resource is likely to remain challenging. As Nye $(2004,99)$ observes, 'soft power resources often work indirectly $[\ldots]$, and sometimes take years to produce the desire outcomes'; furthermore, the multiplicity of potential resources which can strengthen or undermine soft power - and which include interpersonal interactions - could probably only be fully investigated at the level of the individual rather than of any particular group of people. For these reasons, the primary benefits of drawing on the notion of soft power to understand translation phenomena are in my view connected with understanding motivations, intentions, and potential (rather than actual) effects.

\section{Acknowledgements}

This work was supported by the Arts and Humanities Research Council (AHRC) under Grant AH/L007150/1. The author would particularly like to acknowledge the contribution of Sarah Fang Tang who carried out the survey of African literature in China and conducted the interviews with Chinese publishers as part of her work as a research assistant on the project.

\section{Disclosure Statement}

There are no conflicts of interest to report.

\section{Data Availability Statement}

The data that support the findings of this study are available from the corresponding author, KB, upon reasonable request.

\section{Biographical Note}

Kathryn Batchelor is Professor of Translation Studies at UCL, UK. She is the author of Decolonizing Translation: Francophone African Novels in English Translation (2009) and Translation and Paratexts (2018). Her other publications include four co-edited volumes of essays: Translating Thought/Traduire la pensée (2010), Intimate Enemies: Translation in Francophone Contexts (2013), Translating Frantz Fanon across Continents and Languages (2017) and China-Africa Relations: Building Images through Cultural Cooperation. Media Representation and Communication (2017).

\section{References}

AJDHPE. 2012. "Treize socitétés forestières suspendues d'exportation de bois en grumes." AJDHPE-Congo, May 20. http://ajdhpecongo.e-monsite.com/blog/treize-societes- 
$\underline{\text { forestieres-suspendues-d-exportation-de-bois-en- }}$

grumes.html\#3qHwFTmfCpPCF1yr.99

Bandia, Paul. 2008. Translation as Reparation: Writing and Translation in Postcolonial Africa. Manchester: St Jerome Publishing.

Batchelor, Kathryn. 2009. Decolonizing Translation: Francophone African Novels in English Translation. Manchester: St Jerome Publishing.

Batchelor, Kathryn. 2017. “Twenty-first Century Sino-African Cultural Cooperation: Exploring Reciprocity." In China-Africa Relations: Building Images through Cultural Cooperation, Media Representation and Communication, edited by Kathryn Batchelor and Xiaoling Zhang, 75-97. London and New York: Routledge.

Bedjaoui, Mohammed. 2012. "Brief Historical Overview of Steps to African Unity." In The African Union: Legal and Institutional Framework. A Manual on the Pan-African Organization, edited by Abdulqawi A. Yusuf and Fatsah Ouguergouz, 9-23. Leiden: Brill.

Biango, Mingwa. 2010. "Précarité de l'emploi au Congo : L'esclavage est de retour." congoliberty.com, November 26. http://congo-liberty.com/?p=90

Biozi Kiminou, Pascal. 2012. “Littérature : Deux nouveaux livres d'Henri Djombo présentés à Brazzaville.” La Semaine Africaine, November 6. http://www.lasemaineafricaine.net/index.php/culture/5035-litterature-deux-nouveaux$\underline{\text { livres-dhenri-djombo-presentes-a-brazzaville }}$

Breslin, Shaun. 2011. "The Soft Notion of China's 'Soft Power”. London: Chatham House (Asia Programme Paper ASP PP 2011/03).

Cannon, John C. 2016. "Republic of Congo Awards Two Million Hectares of Timber Concessions." Mongabay: News and Inspiration from Nature's Frontline, February 
11. https://news.mongabay.com/2016/02/republic-of-congo-awards-two-millionhectares-of-timber-concessions/

Casanova, Pascale. 2007. The World Republic of Letters. Translated by Malcolm DeBevoise. Cambridge, Mass: Harvard University Press.

China Daily. 2012. “Beyond Diplomatic Language.” China Daily, 9 October. http://www.chinadaily.com.cn/china/2012-10/09/content_16385930.htm

China's Forbidden News. 2011. "Jiang Zemin: 'Gadhafi is My Close Friend'”. China's Forbidden News, 26 October. [online video]. https://www.youtube.com/watch?v=N7aymUXz6Rc

Chinese Foreign Ministry. 2006. China.org.cn, October 10. http://www.china.org.cn/english/features/focac/183438.htm

Chorin, Ethan. 2015. Translating Libya: In Search of the Libyan Short Story. London: Darf Publishers.

Columbia University Libraries. 2018. "Africa's 100 Best Books of the $20^{\text {th }}$ Century." Columbia University Libraries. Accessed March 52018. http://library.columbia.edu/locations/global/virtual$\underline{\text { libraries/african_studies/books.html }}$

Congo-SiteOfficiel. 2010. "Visite de travail d'Henri Djombo en Chine." Congo-SiteOfficiel JTV-CONGO, November 11 [online video]. http://www.dailymotion.com/video/xfod0a_visite-de-travail-d-henri-djombo-enchine news

de Villiers, Phillippa Yaa. 2010. “Preface.” In No Serenity Here. An Anthology of African Poetry in Amharic, English, French, Arabic and Portuguese, edited by Phillippa Yaa 
de Villiers, Isabel Ferrin-Aguirre and Xiao Kaiyu, i-ix. Beijing: New Knowledge Publishing House.

Ding, Sheng. 2008. “To Build a 'Harmonious World': China's Soft Power Wielding in the Global South". Journal of Chinese Political Science 13 (2):193-213.

Embassy of the People's Republic of China in the Republic of Senegal. 2007. "Le Président Hu Jintao a recontré le Président sénégalais Abdoulaye Wade.” June 8. http://sn.china-embassy.org/fra/xwdt/t328730.htm

Forest Stewardship Council. 2014. “H. E. Henri Djombo.” http://ga2014.fsc.org/h-e-henridjombo

Gil, Jeffrey. 2017. Soft Power and the Worldwide Promotion of Chinese Language Learning: The Confucius Institute Project. Bristol: Multilingual Matters.

Gilbert, Catherine. 2017. “China Corner: Chinese Book Donations to Africa.” In ChinaAfrica Relations: Building Images through Cultural Cooperation, Media Representation and Communication, edited by Kathryn Batchelor and Xiaoling Zhang, 113-28. London and New York: Routledge.

Global Forest Watch. 2018. "Republic of Congo Logging Concessions.” Global Forest Watch. Accessed March 52018. http://data.globalforestwatch.org/datasets/557bfc901c584b7a8884aa455cfa6de2_19

Hall, Todd. 2010. “An Unclear Attraction: A Critical Examination of Soft Power as an Analytical Category." The Chinese Journal of International Politics. 3.2: 189-211.

Heilbron, Johan and Gisèle Sapiro. 2007. "Outline for a Sociology of Translation: Current Issues and Future Prospects." In Constructing a Sociology of Translation, edited by Michaela Wolf and Alexandra Fukari, 93-107. Amsterdam: John Benjamins. 
Ikome, Francis. 2010. "The Role and Place of the African Union in the Emerging ChinaAfrica Partnership.” In Chinese and African Perspectives on China in Africa, edited by Axel Harneit-Sievers, Stephen Marks and Sanusha Naidu, 201-12. Cape Town, Dakar, Nairobi and Oxford: Pambazuka Press.

Jacquemond, Richard. 1992. "Translation and Cultural Hegemony: The Case of FrenchArabic Translation.” In Rethinking Translation, edited by Lawrence Venuti, 139-158. New York and London: Routledge.

Kaiyu, Xiao. 2010. “Introduction.” In No Serenity Here. An Anthology of African Poetry in Amharic, English, French, Arabic and Portuguese, edited by Phillippa Yaa de Villiers, Isabel Ferrin-Aguirre and Xiao Kaiyu, x-xiii. Beijing: New Knowledge Publishing House.

Kalder, Daniel. 2010. “Dictator-lit: Gadaffi’s Surreal Gibberish.” The Guardian, March 24. https://www.theguardian.com/books/booksblog/2010/mar/24/dictator-lit-gaddafi

King, Kenneth. 2013. China's Aid and Soft Power in Africa: The Case of Education and Training. Woodbridge: James Currey.

King, Kenneth. 2017. "Confucius Institutes in Africa: Culture and Language without Controversy?" In China-Africa Relations: Building Images through Cultural Cooperation, Media Representation and Communication, edited by Kathryn Batchelor and Xiaoling Zhang, 98-112. London and New York: Routledge.

Kong, Shuyu. 2005. Consuming Literature: Best Sellers and the Commercialization of Literary Production in Contemporary China. Stanford: Stanford University Press. Lambert, José. 1995. "Literature, Translation and (De)Colonization." In Translation and Modernization, edited by Theresa Hyun and José Lambert, 98-117. Tokyo: Tokyo University Press. 
Lawson, Sam. 2014. "Illegal Logging in the Republic of Congo." London: Chatham House (Energy, Environment and Resources EER PP 2014/02)

Lefkowitz, Melissa. 2017. "Revolutionary Friendship: Representing Africa during the Mao Era." In China-Africa Relations: Building Images through Cultural Cooperation, Media Representation and Communication, edited by Kathryn Batchelor and Xiaoling Zhang, 29-50. London and New York: Routledge.

Li, Shubo and Helge Roenning. 2013. "Winning Hearts and Minds: Chinese Soft Power Foreign Policy in Africa.” Bergen: Chr. Michelsen Institute (CMI Brief 12.3).

Liu, Haifang. 2008. "China-Africa Relations through the Prism of Culture - The Dynamics of China's Cultural Diplomacy with Africa." China aktuell Journal of Current Chinese Affairs 3: 9-44.

Lubabu, Tshitenge. 2008. "Henri Djombo". Jeune Afrique, May 13. http://www.jeuneafrique.com/112909/politique/henri-djombo/

Maluwa, Tiyanjana. 2012. "The Transition from the Organization of African Unity to the African Union." In The African Union: Legal and Institutional Framework. A Manual on the Pan-African Organization, edited by Abdulqawi A. Yusuf and Fatsah Ouguergouz, 25-52. Leiden: Brill.

Michel, Serge and Michel Beuret. 2008. La Chinafrique: Pékin à la conquête du continent noir. Paris : Editions Grasset \& Fasquelle.

Ministry of Foreign Affairs of the People's Republic of China (PRC). 2001. "Libyan Leaders Meet Foreign Minister Tang Jiaxun.” January 12.

http://www.fmprc.gov.cn/mfa_eng/wjb_663304/zzjg_663340/xybfs_663590/gjlb_663 594/2848_663686/2850_663690/t16389.shtml 
Ministry of Foreign Affairs of the People's Republic of China (PRC). 2004a. "Characteristics of FOCAC.” http://www.fmprc.gov.cn/zflt/eng/gylt/ltjj/t157576.htm

Ministry of Foreign Affairs of the People's Republic of China (PRC). 2004b. "Overview of Africa." http://www.focac.org/eng/zjfz/fzzl/

Ministry of Foreign Affairs of the People's Republic of China (PRC). 2006. "Entretien entre le Président Hu Jintao et le Président sénégalais Abdoulaye Wade.” http://www.mfa.gov.cn/fra/wjb/zzjg/fzs/fzsgjlb/1630/1632/t259907.shtml

Nederhood, Joshua. 2018. "Where are Foreign Cultural Institutes in Africa?" https://public.tableau.com/profile/joshua.nederhood4406\#!/vizhome/WhereareForeign CulturalInstitutesinAfrica/WhereareForeignCulturalInstitutesinAfrica

Nye, Joseph S. 2004. Soft Power: The Means to Success in World Politics. New York: Public Affairs.

Nye, Joseph S. 2008. "Public Diplomacy and Soft Power." Annals of the American Academy of Political and Social Science 616 (March): 94-109.

People’s Daily Online. 2006. “Full Text: China’s African Policy.” January 12. http://english.peopledaily.com.cn/200601/12/eng20060112_234894.html\#

Rothman, Steven B. 2011. "Revising the Soft Power Concept: What are the Means and Mechanisms of Soft Power?” Journal of Political Power 4.1: 49-64.

Rowe, Raphael. 2013. "Has the EU Fallen for Congo Rainforest Logging Scam?” BBC News, July 22. http://www.bbc.co.uk/news/world-africa-23358055

Salinger, Pierre. 1999. "Foreword." In Escape to Hell and Other Stories by Muammar Gadaffi. vii-xxix. London: Blake Publishing Ltd. 
SEFYD. 2018. "La visite du Ministre Henri Djombo.” SEFYD. Accessed March 52018. http://sefyd.com/fr/newsview.asp?id=51

Shuman, Amanda. 2017. "Giving 'Prominence to Politics: African Sportsmen Visit China in the Early Cultural Revolution.” In China-Africa Relations: Building Images through Cultural Cooperation, Media Representation and Communication, edited by Kathryn Batchelor and Xiaoling Zhang, 51-72. London and New York: Routledge.

St John, Ronald Bruce. 2014. Historical Dictionary of Libya. Fifth Edition. Lanham, Boulder: Rowman \& Littlefield).

Stiles, Daniel. 2014. "Flying Under the Radar in Central Africa, Chinese Companies May Be Wreaking Environmental Havoc.” Mongabay: News and Inspiration from Nature's Frontline, November 7. https://news.mongabay.com/2014/11/flying-under-the-radarin-central-africa-chinese-companies-may-be-wreaking-environmental-havoc/

Sun, Ji, Yang Yang and Meng Mao. 2009. "The Current Status of the Publishing Industry in China.” Journal of Scholarly Publishing 41.1: 92-102.

Venuti, Lawrence. 1995. The Translator's Invisbility: A History of Translation. London and New York: Routledge.

Wade, Abdoulaye. 2008. "Time for the West to practise what it preaches." Financial Times, January 23. http://www.ft.com/cms/s/0/5d347f88-c897-11dc-94a6$\underline{\text { 0000779fd2ac.html\#axzz30Z7ZUexH }}$

World Wildlife Fund (WWF-UK). 2005. "Failing the Forests - Europe's Illegal Timber Trade.” November 1. assets.panda.org/downloads/failingforests.pdf

Xinhua. 2011. "Congo: un projet de transformation de bois par la société chinoise FOMA." Ministry of Foreign Affairs of the People's Republic of China [website] January 27. http://wcm.fmprc.gov.cn/pub/zflt/fra/zfgx/jmhz/t790343.htm 
Xinhau, 2012. "Congo: neuf ministres primés par l'Association Congo-Chine-First." www.focac.org, February 2. http://www.focac.org/fra/zxxx/t901047.htm

Zhang, Zhongxiang. 2010. “Africa Joint Pavillion - Shanghai World Expo: Not to be Missed." People’s Daily, May 21.

http://www.fmprc.gov.cn/zflt/eng/zfgx/rwjl/t696790.htm 